\title{
13. JURASSIC SEDIMENTS, SITE 547, NORTHWEST AFRICAN MARGIN: REMARKS ON STRATIGRAPHY, FACIES, AND DIAGENESIS, AND COMPARISON WITH SOME TETHYAN EQUIVALENTS ${ }^{1}$
}

\author{
Daniel Bernoulli, Geologisches Institut der Universität Basel \\ and \\ Otto Kälin, Dipartimento di Scienze della Terra, Università di Pisa ${ }^{2}$
}

\begin{abstract}
On Leg 79 of the Deep Sea Drilling Project, a Jurassic continental margin was drilled for the first time allowing closer comparison with Jurassic continental margin deposits on land. The Jurassic sedimentary sequence recovered at Site 547 shows many analogies to Tethyan sequences, thus confirming inferences drawn from Mesozoic sequences in the Alpine-Mediterranean area.

After initial rifting in the Late Triassic and earliest Liassic, the Sinemurian-Pliensbachian sediments at Site 547 record the first marine transgression in the central Atlantic with a rapid passage from a continental to a basinal and hemipelagic regime: ongoing synsedimentary faulting and the resulting steep submarine topographic gradients are suggested during this time by sediment gravity flow deposits involving both displaced shallow-water and basinal sediments. A mineralogically mixed composition, with a significant contribution of platform-derived carbonate lutum, is similarly suggested for fine-grained slope and basinal deposits. In some cases, complexly organized breccias with evidence for multiple breakage of constituent clasts and postdepositional fracturing in various successive generations place the depositional setting of the Jurassic sediments of Site 547 near or on a submarine faulted slope. Further evidence for an unstable slope environment are probable gaps that are due to nondeposition and/or submarine erosion.

Gradual sinking of the margin in Middle and Late Jurassic times is reflected at Site 547 by decreasing sedimentation rates. There is a relative increase in pelagic sediments and components in gravity flow sediments with respect to redeposited shallow-water material. Unstable conditions, however, persisted throughout the Jurassic as suggested by recurrent intercalations of coarse breccias.
\end{abstract}

\section{INTRODUCTION}

The principal objective of Leg 79 was to document the environment of rifting and the subsidence history of the Mazagan Escarpment, a segment of the passive margin bordering the Jurassic central Atlantic. In this context, it is noteworthy that for the first time a starved continental margin of the Jurassic-Early Cretaceous, Atlantic-Tethyan ocean has been drilled. All other sites where Jurassic sediments were reached were situated on oceanic crust and comparisons of deformed Tethyan margins with undeformed counterparts had to rely generally on the facies of deep-water sediments (Bernoulli, 1972; Bernoulli and Jenkyns, 1974), on depositional geometry derived from seismic reflection data, or on analogies with younger margins of Late Cretaceous age (Graciansky et al., 1979). These former comparisons are now generally confirmed by the "Tethyan facies" encountered in the Jurassic sequences of the sites along the Mazagan margin.

The Mazagan Plateau off the Moroccan coast is built up by a Jurassic-Lower Cretaceous carbonate platform, overlain by Upper Cretaceous to Cenozoic hemipelagic and clastic sediments. In the west and northwest, the carbonate platform is truncated by faults and the plat-

\footnotetext{
${ }^{1}$ Hinz, K., Winterer, E. L., et al., Init. Repts. DSDP, 79: Washington (U.S. Govt. Printing Office).

Addresses: (Bernoulli) Geologisches Institut der Universităt Basel, 32 Bernoullistr. CH-4056 Basel, Switzerland; (Kälin) Dipartimento di Scienze della Terra, Università di Pisa, Via Santa Maria 53, 56100 Pisa, Italy.
}

form crops out along the Mazagan Escarpment from which Oxfordian shallow-water limestones have been dredged (Renz et al., 1975). Along the deeply submerged margin, seaward of the Mazagan Escarpment, four holes were drilled during Leg 79 (Fig. 1). Site 545 is situated near the foot of the Mazagan Escarpment and recovered, below a cover of Middle Cretaceous and Miocene to Quaternary hemipelagic sediments, a sequence of partly dolomitized shallow-water limestones of ?Middle to Late Jurassic age. Site 544 is situated on a continental basement high in the distal part of the margin. At this site, Miocene to Quaternary hemipelagic sediments overlie about $40 \mathrm{~m}$ of reddish "oncoid"-bioclast-intraclast limestones of ?Middle to Late Jurassic age that, in turn, rest on presumably Upper Triassic or Lower Liassic gray mudstones and sandstones and Paleozoic gneiss. Site 547 is located down the plunge of the same structure drilled at Site 544. Separated from Site 544 by a number of normal faults, it shows a much thicker sedimentary sequence (Fig. 2). Below a 773-m-thick sequence of pelagic, hemipelagic, and mass-flow deposits of Albian-Cenomanian and Late Cretaceous to Quaternary age, about $150 \mathrm{~m}$ of Jurassic to lowermost Cretaceous sediments overlie Late Triassic to Early Liassic sandstones and mudstones similar to those of Site 544. The Lower Liassic to ?Hauterivian sequence is very heterogeneous and consists of pelagic to hemipelagic limestones and marls with intercalated sediment gravity flow deposits, some of debris-flow origin and, in part with displaced shallow-water limestone lithologies (Fig. 3). Site 546, 


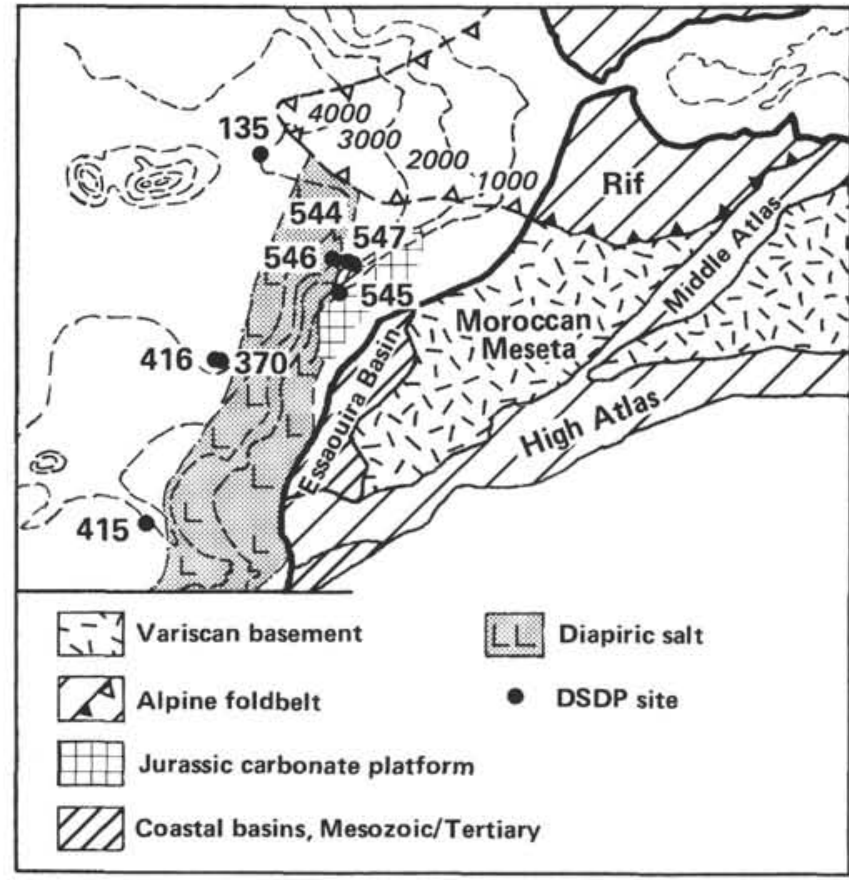

Figure 1. Location and tectonic setting of DSDP sites, Northwest African continental margin.

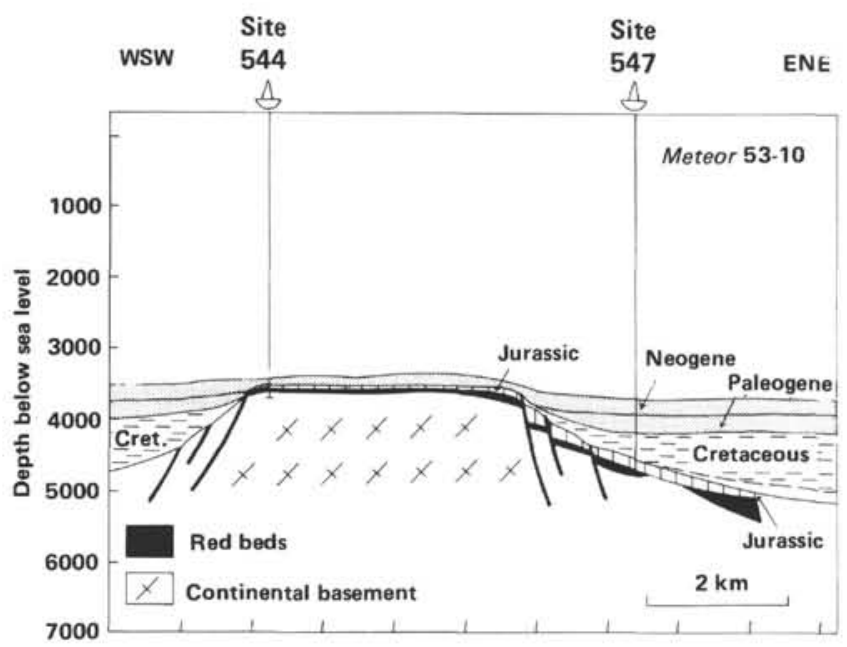

Figure 2. Cross section, based on multichannel seismics, across the outer basement high, Mazagan continental margin.

drilled on a diapiric high seaward of Site 544, yielded Triassic salt below a Miocene cover.

The Triassic to lowermost Liassic deposits reflect stages of rifting in an essentially continental setting with incursions or infiltration of marine waters during evaporite deposition. This same history of early graben formation, accompanied by red bed sedimentation and later by alkaline volcanic activity and evaporite deposition, is also well documented from both sides of the central Atlantic in Morocco on land and along the Nova Scotia continental margin (Van Houten, 1977; Lancelot, 1980; Lancelot and Winterer, 1980; Jansa and Wiedmann, 1982; Manspeizer et al., 1978).

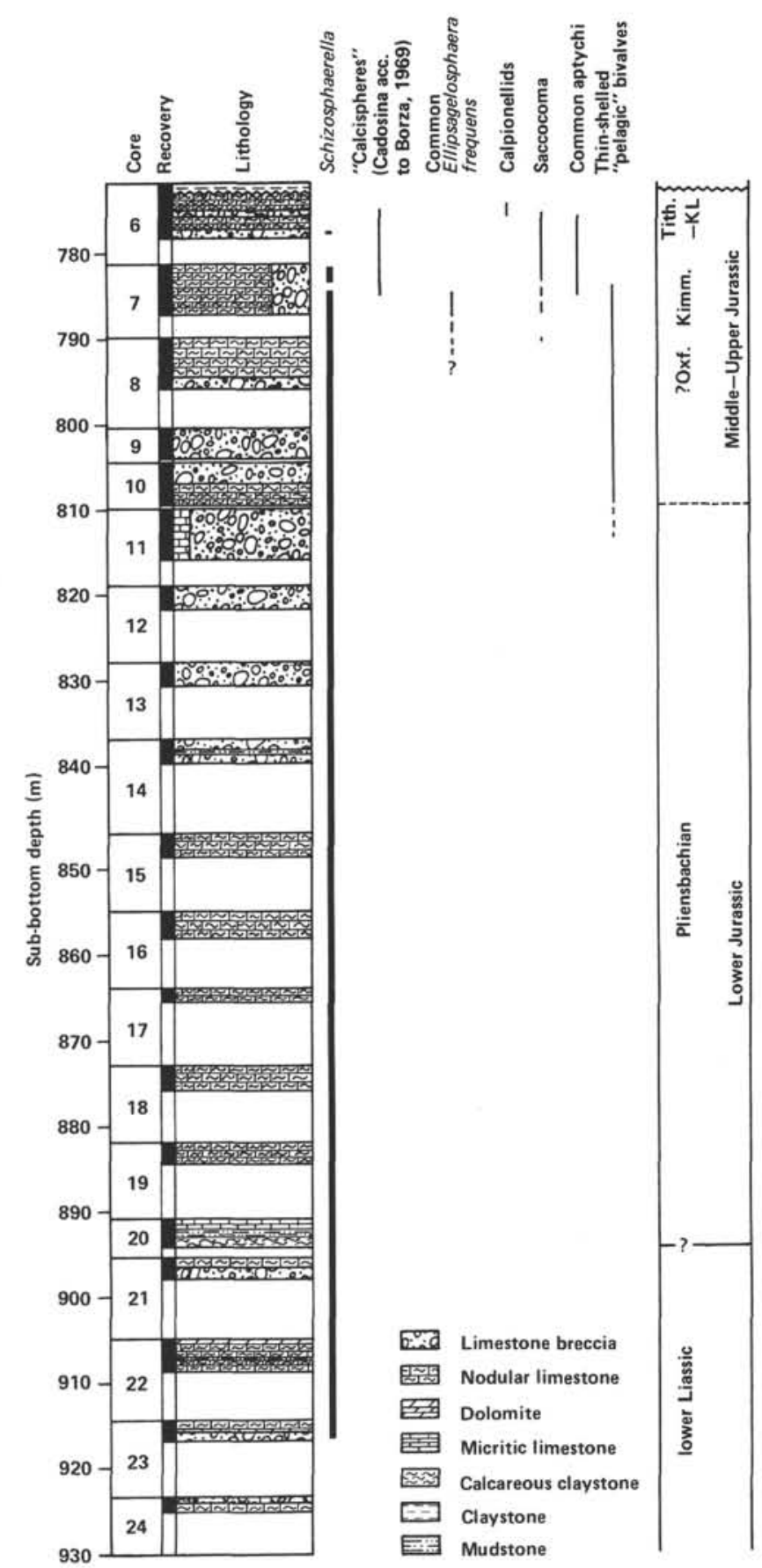

Figure 3. Jurassic lithologic sequence recovered from Hole 547B and stratigraphic occurrence of Schizosphaerella in relation to other important Jurassic fossil groups.

The Liassic (Sinemurian to Pliensbachian) deposits at Site 547 record the first truly marine transgression in the central Atlantic (Lancelot, 1980). As there is a very rapid vertical facies change from continental to marine hemipelagic and sediment gravity flow deposition, this transgression obviously affected an area with a considerable relief and already differentiated into morphological highs and depressions by block faulting. The early history of the future margin is poorly documented, however, the persistence of this morphological differentia- 
tion and of block-faulting throughout the Liassic is suggested by the frequent intercalations of gravity flow breccias at Site 547. Continuous deep-water conditions from the Sinemurian into the Early Cretaceous at Site 547 further show that early spreading occurred in a fully marine environment, contrary to previous reconstructions (Lancelot, 1980; Lancelot and Winterer, 1980, fig. 27C).

During the Middle and Late Jurassic a thick carbonate platform developed along the proximal Mazagan margin. Such carbonate platforms, with rapid subsidence balanced by carbonate production in the photic zone, are well documented for the central Atlantic margins, particularly for the Late Jurassic (e.g., Bhat et al., 1975; Jansa, 1981; Ryan and Miller, 1981). The platform margins constituted the source areas of redeposited carbonate material in the adjacent basins (Schlager, 1980).

Whereas faulting activity in rifted continental margins generally decreases with the onset of spreading and continental drift, along the Mazagan margin ongoing differential subsidence and block faulting is suggested by the differences in facies and formation thicknesses of the Jurassic sediments. A particular problem is posed by the discontinuous deposition of Upper Jurassic shallowwater limestones in the distal continental margin: the sedimentary evolution at Site 544 suggests a very specific subsidence history for this site, possibly in connection with transform movements in the segment between the South Atlas-Canary lineament and Azores-Gibraltar fracture zone.

We shall briefly summarize the sedimentary sequence at Site 547 in this chapter and illustrate some of its facies similarities with Tethyan counterparts. For a discussion of aspects of diagenesis, see Kälin and Bernoulli (this volume).

\section{FACIES}

The Jurassic carbonate sequence (Lithologic Unit VI) of Site 547 overlies the grayish red to grayish green and brown sandy claystones and mudstones of Unit VII rather abruptly. In the upper part of Unit VII, the mudstones and claystones are calcareous to dolomitic; lower down they occasionally contain gypsum. The upper part of Unit VII has been dated as Rhaetian to Hettangian by pollen (Fenton, this volume). This unit is thought to have been deposited in a continental environment with mainly granitic source terranes.

Unit VI has been subdivided into two subunits, A and B, from top to bottom. For easy reference to the site chapter, we shall follow this subdivision. The general lithologic sequence recovered and the occurrence of Schizosphaerella together with some other important Jurassic fossil groups are represented in Figure 3.

\section{Subunit VIB, Lower Part (Cores 547B-20 to 547B-24; 891 to $932.5 \mathrm{~m}$ sub-bottom)}

This subunit consists mainly of marly limestones to calcareous mudstones, gray to greenish and olive gray, sometimes reddish gray in color, limestone breccias, and nodular limestones. Near the base of the subunit (547B23-2, 40-62 cm), light olive gray limestones occur. Steiger and Jansa (this volume) interpret these limestones as stromatolithic boundstones; our thin-section examination, however, does not support this interpretation. Sample 547B-23-2, 57-59 cm shows a fabric of microsparite with a few finer-grained streaks and patches, occasionally with a clotty texture. Sample 547B-23-2, 39-41 cm is a clotty to flaser-textured micrite to microsparite with calcite-cemented bio-molds. This sample also contains Schizosphaerella punctulata and $S$. astrea (see Table 1 in Kälin and Bernoulli, this volume) and is better interpreted as a basinal, off-platform limestone.

The samples of limestone breccia we investigated (547B-22-2, 110-113 cm; 547B-22-2, 74-76 cm) have a red clay-bearing microsparitic matrix with $\mathrm{mm}$ - to some $\mathrm{cm}$-sized, generally closely packed limestone clasts of various lithologies. The clasts comprise fragments of microsparitic clotty limestones similar to those found in Core 547B-23, pelletal lime wackestones to packstones with small cyanobacterian nodules, microbioclastic wackestones, some with calcite-cemented solution molds of sponge spicules. Some of the clasts and parts of the matrix contain Schizosphaerella punctulata and S. astrea. The components usually show long contacts with incipient pressure-solution welding. Comparison with similar limestone breccias from the Tethyan Jurassic suggests that these lithologies were deposited by gravity flow processes (debris flow). The microfacies of the micritic limestone fragments with sponge spicules, bioclasts and small cyanobacterian nodules, conspicuously resembles that of Lower Jurassic peri-platform limestones of the Tethyan realm. Such clasts typically occur in mass-flow deposits of Sinemurian-Carixian age in basins adjacent to carbonate platforms (e.g., Corniola Formation of the central Apennines, see Fig 4). The nodular limestones have a pale brown matrix of clay-rich microsparite with $\mathrm{mm}$ - to $\mathrm{cm}$-sized irregularly shaped fragments and nodules of microbioclastic lime wackestone. Both matrix and nodules are rich in Schizosphaerella.

In 547B-22-1 dolomites with a microsparitic, hypidiotopic fabric occur. Sample 547B-20,CC (33-35 cm) is a gray, flaser-textured limestone with the original lamination disturbed by intense burrowing (Fig. 5A). The fine-grained matrix of this limestone has altered largely to microspar and contains some dolomite rhombs; the microfacies is similar to that of basinal Lower Liassic limestones in the Tethyan belt (e.g., Lombardian Siliceous Limestones, (Fig. 5B).

The occurrence of Involutina ticinensis (Schweighauser) together with Schizosphaerella in a limestone clast (Sample 547B-22-2, 110-113 cm) sets a maximum age of Early Liassic for this subunit. This agrees with the Sinemurian age established by Riegraf et al. (this volume).

\section{Subunit VIB, Upper Part (547B-14-2, $37 \mathrm{~cm}$ to Core 547B-19: 839 to $891 \mathrm{~m}$ sub-bottom)}

Cores 547B-15 to 547B-19 consist of nodular limestones with irregularly shaped, pale yellowish brown to pale red limestone nodules set in a pale brown to grayish olive marl matrix. The nodules are either closely packed with styolithic contacts or float in the matrix. Our samples show the limestone fragments to be faintly pelleted lime mud- to wackestones with fine biogenic compo- 

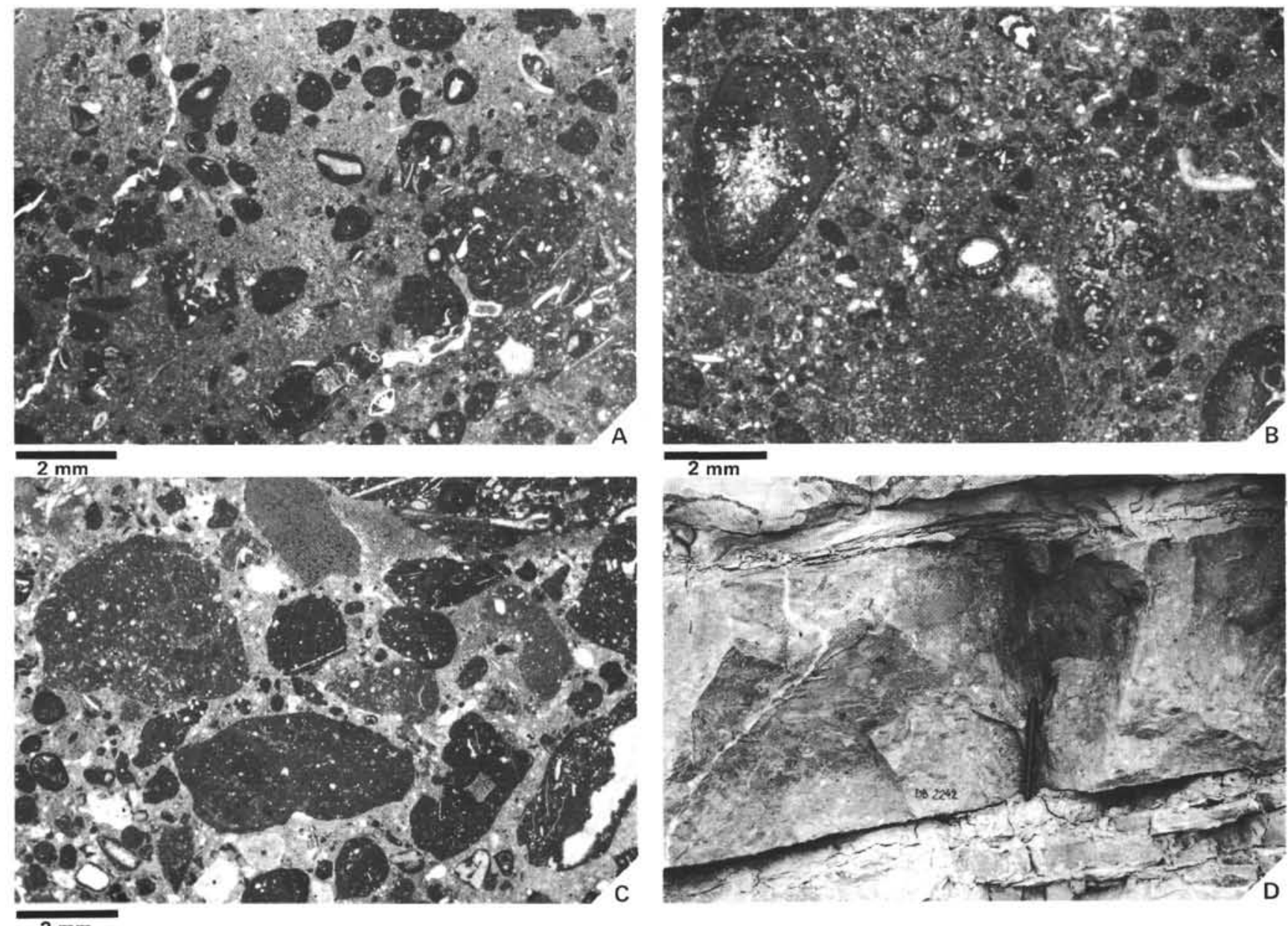

$2 \mathrm{~mm}$

Figure 4. Redeposited calcirudites with shallow-water carbonate material, Lower and Middle Jurassic, Site 547 and Mediterranean Tethys. A. Small, irregularly shaped, cyanobacterial nodules (oncoids) and coated skeletons set in a largely microsparitic groundmass, resulting from neomorphic replacement of an original muddy lime matrix. Subunit VIA, lower part, ?Middle Jurassic, Sample 547B-9-1, 19-21 cm. Thin section, plane light. B. Calcareous algae and other biogenic material, encrusted by fine-grained cyanobacterial carbonate and sessile foraminifers in a matrix of neomorphic microsparite and micrite. Lithoclasts of pelleted spiculitic limestone (for detail, see Fig. 6B) are similar to clasts of spiculitic limestone in breccias of Subunit VIA, lower part. Sample from breccia bed illustrated in Fig. 4D; Corniola Formation, Sinemurian to lower Pliensbachian, Torrente Bosso, Umbrian Apennines, central Italy. Thin section, plane light. C. Clasts of shallow-water limestones and shallow-water biota with cyanobacterial coatings in a microsparitic groundmass. Microsparite and syntaxial overgrowths around echinoderm ossicles are of neomorphic replacement origin. Subunit VIA, lower part, ?Middle Jurassic, Sample 547B-9-2, 106-109 cm. Thin section, plane light. D. Calcirudite with clasts of penecontemporaneous shallow-water limestones and bioclastic material. The bed is approximately $35 \mathrm{~cm}$ thick and occurs within a sequence of calcirudites and graded calcarenites, with interbedded thin marls and, subordinately, basinal radiolariansponge-spicule limestones. Large slump-sheets, also involving earlier debris-flow deposits, and channelized breccias occur in the same section. Corniola Formation, Sinemurian-lower Pliensbachian, Torrente Bosso, Umbrian Apennines, central Italy.

nents, mainly calcite-cemented radiolarian molds and possible fragments of thin-shelled bivalves, sponge spicules, and echinoderms. Schizosphaerella (S. punctulata and astrea) is common to abundant both in the limestone nodules and in the hematite-stained, microsparitic matrix. Occasionally burrows with a geopetal infill of fine sediment, now microsparite, are observed. The occurrence of Schizosphaerella punctulata and S. astrea agrees with an early Pliensbachian age as established by Riegraf et al. (this volume).

The nodular limestones of this interval are closely similar to some varieties of Rosso Ammonitico occurring in the Tethyan Liassic; see also Bernoulli, 1972; Bernoulli and Jenkyns, 1970; 1974). The irregular shape and arrangement of the nodules in many cases suggest remobilization by gravitational mass movement, in some cases possibly by debris flow. The occurrence of breccias composed of different pelagic and hemipelagic lithologies in this interval (Steiger and Jansa, this volume) supports this interpretation.

\section{Subunit VIA, Lower Part (547B-8-3, $145 \mathrm{~cm}$ to 547B-14-2, $37 \mathrm{~cm}$; 745.5 to $839 \mathrm{~m}$ sub-bottom)}

The nodular limestones of the upper part of Subunit VIB are overlain by an interval dominated by limestone breccias. These breccias show a wide variety of clast lithology and of sedimentary structures and diagenetic fabrics. Different breccia levels are separated by early lithified fine-grained intervals ("micritic crusts", Steiger and Jansa, this volume), thus indicating different events of redeposition. The lower part of Subunit VIA is subdivided by an intercalation of nodular limestones (547B- 

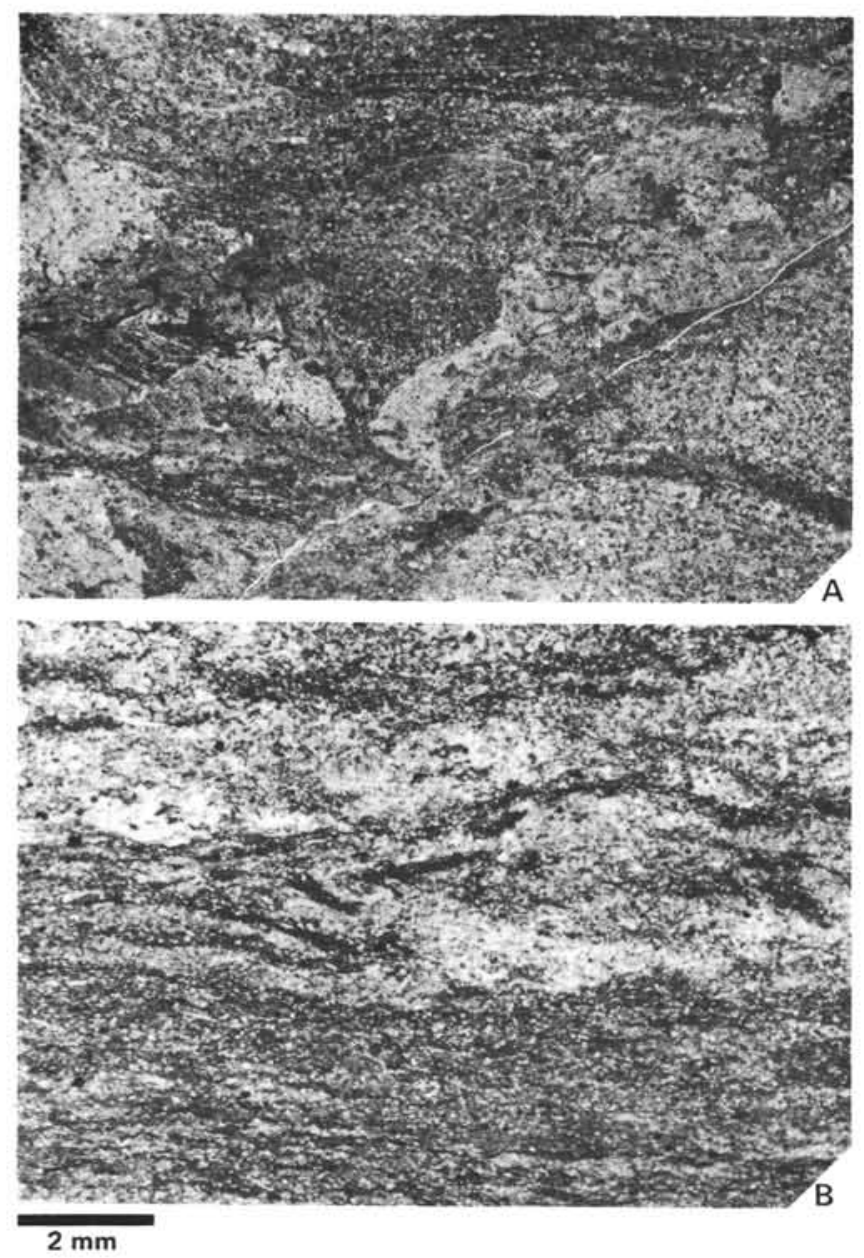

Figure 5. Burrowed, slightly marly calcisiltites to calcilutites. A. Subunit VIB, lower part, ?upper Sinemurian-lower Pliensbachian, Sample 547B-20,CC (33-35 cm). B. Spiculitic calcisiltite to calcilutite, Lombardian Siliceous Limestone, Sinemurian, Monte Generoso, Lombardian Zone, southern Alps, southern Switzerland. Both limestones contain Schizosphaerella and are interpreted as basinal sediments; the example from the southern Alps was deposited in a fault-bounded basin during early rifting of the southern margin of the Tethyan ocean. Thin sections, plane light.

$10-3$; 547B-10-4) into a lower and an upper breccia interval distinguished by clast lithology. The breccias from 547B-14-2 through 547B-11-4 are clast-supported with the components in cases closely packed and meeting along sutured contacts. Between larger clasts, the interstitial sediment is sometimes geopetally arranged with the remaining pore space cemented by blocky calcite. The interstitial sediment is replaced by neomorphic microspar; around echinoderm fragments neomorphic syntaxial rims occur mimicking cementation by blocky calcite. The clasts are mainly reddish-brown marly limestone, microbioclastic wackestone containing calcitecemented molds of radiolarians, molluscan shell debris, foraminifers (including Involutina ticinensis [Schweighauser]) as well as echinoderm fragments, silty marl, calcareous siltstone, and sandstone. Subordinately, peloidal pack- to grainstones with calcite-cemented molds of sponge spicules (Fig. 6A) and occasional ostracodes and foraminifers occur. Intercalated greenish-gray to wine-red
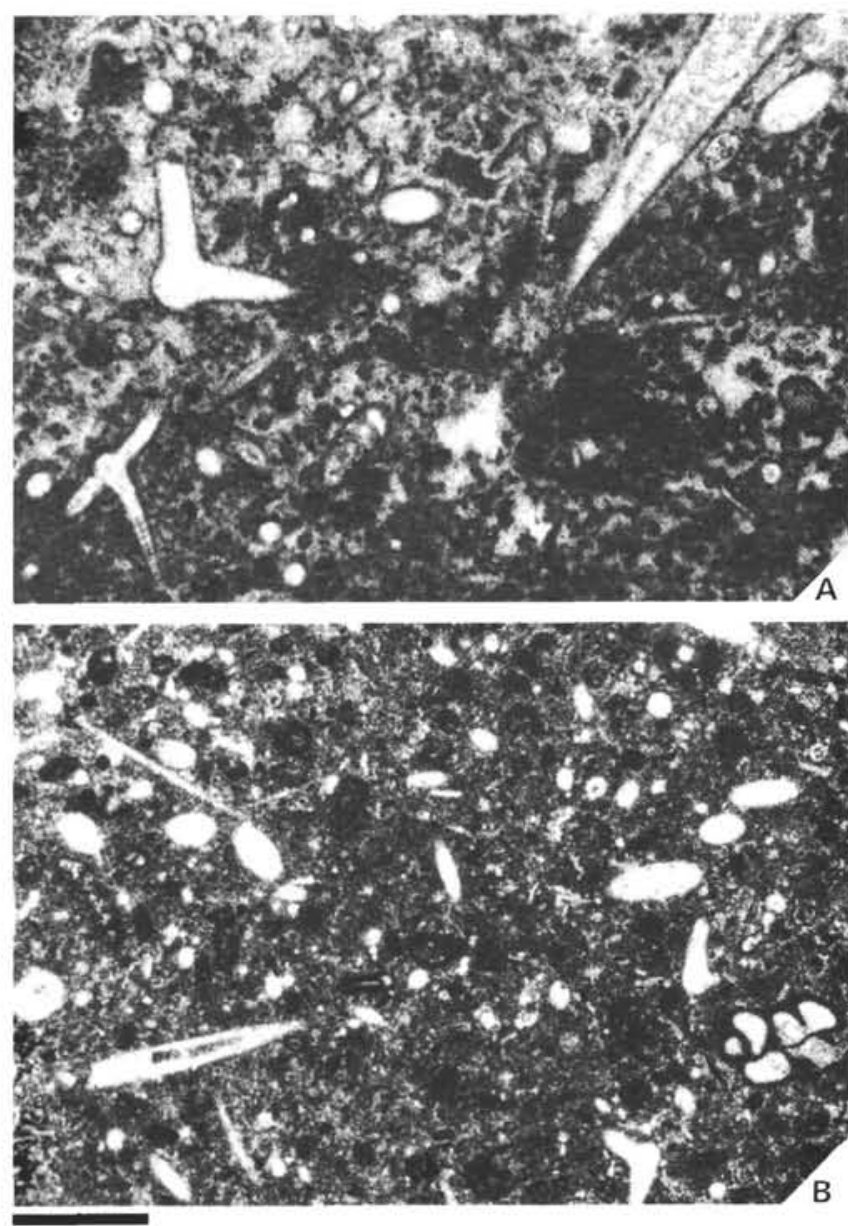

$0.5 \mathrm{~mm}$

Figure 6. Spiculitic limestones. A. Peloidal pack- to grainstone with calcite-cemented molds of sponge spicules and subordinate foraminifers and ostracodes. Component in clast-supported breccia. Subunit VIA, lower part, Pliensbachian, Sample 547B-12-1, 46-48 $\mathrm{cm}$. B. Lime packstone with small cyanobacterial nodules and calcite-cemented molds of sponge spicules. Clast in debris-flow deposit (Fig. 4B, D). Corniola Formation, Sinemurian-lower Pliensbachian, Torrente Bosso, Umbrian Apennines, central Italy. Thin sections, plane light.

calcareous mud- and sandstones are rich in terrigenous quartz, feldspar, and fragments of crystalline basement rocks.

The breccias of 547B-11-3 to 547B-11-1 show very complex sedimentary and diagenetic fabrics (Fig. 7B, C, E). The constituent clasts are irregularly shaped, cmsized and larger, and consist of microbioclastic wackestone with calcite-cemented radiolarian molds and/or thin-shelled bivalves, echinoderm fragments, and other biota. Some of the limestone clasts contain small oncoids, and peloidal pack/grainstones with sponge spicules also occur. The geopetally infilled sediment in frame interstices is a wackestone with echinoderm fragments and foraminifers in a micrite matrix that is, however, coarser than in the clasts. This is generally followed by a second generation of geopetally infilled sediment, now microspar, which in turn is overlain by blocky calcite cement (for details see Fig. 7).

The nedular limestones of 547B-10-3 and 547B-10-4 are pale green or reddish brown with nodules of marly 


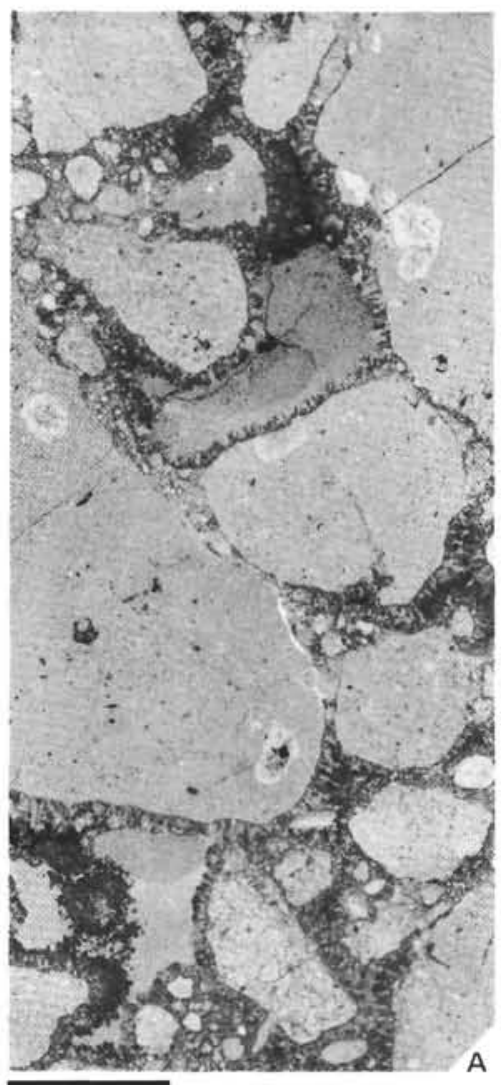

$1 \mathrm{~cm}$

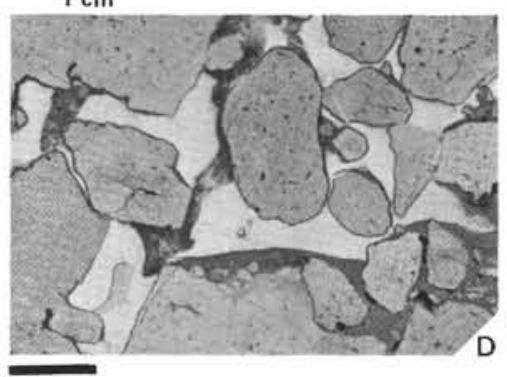

$1 \mathrm{~cm}$

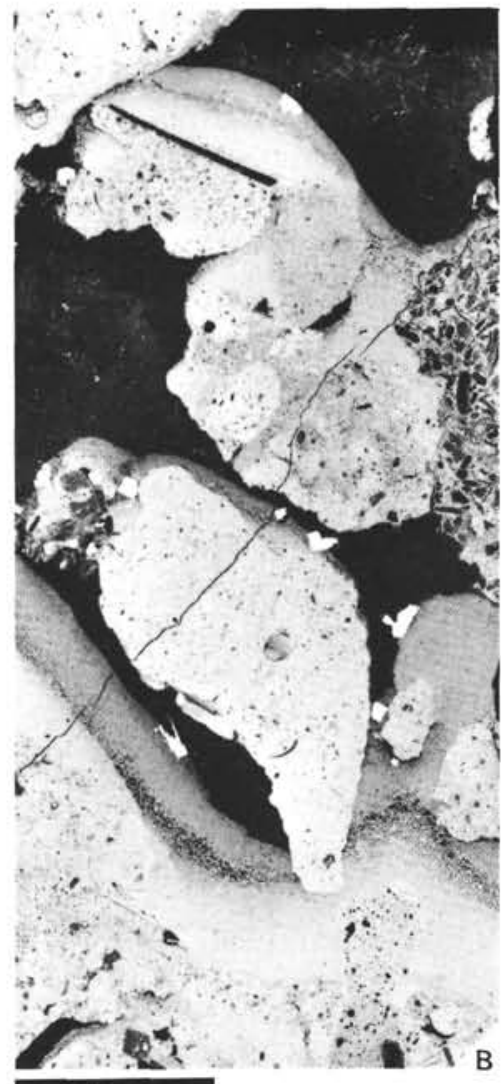

$0.5 \mathrm{~cm}$

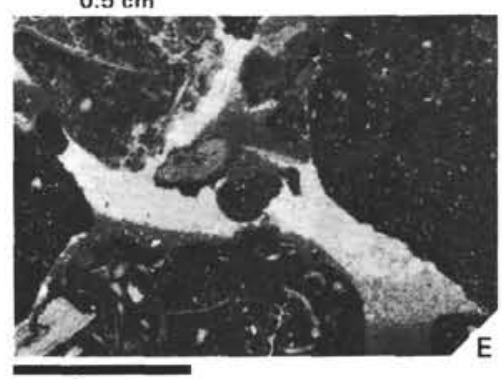

$2 \mathrm{~mm}$
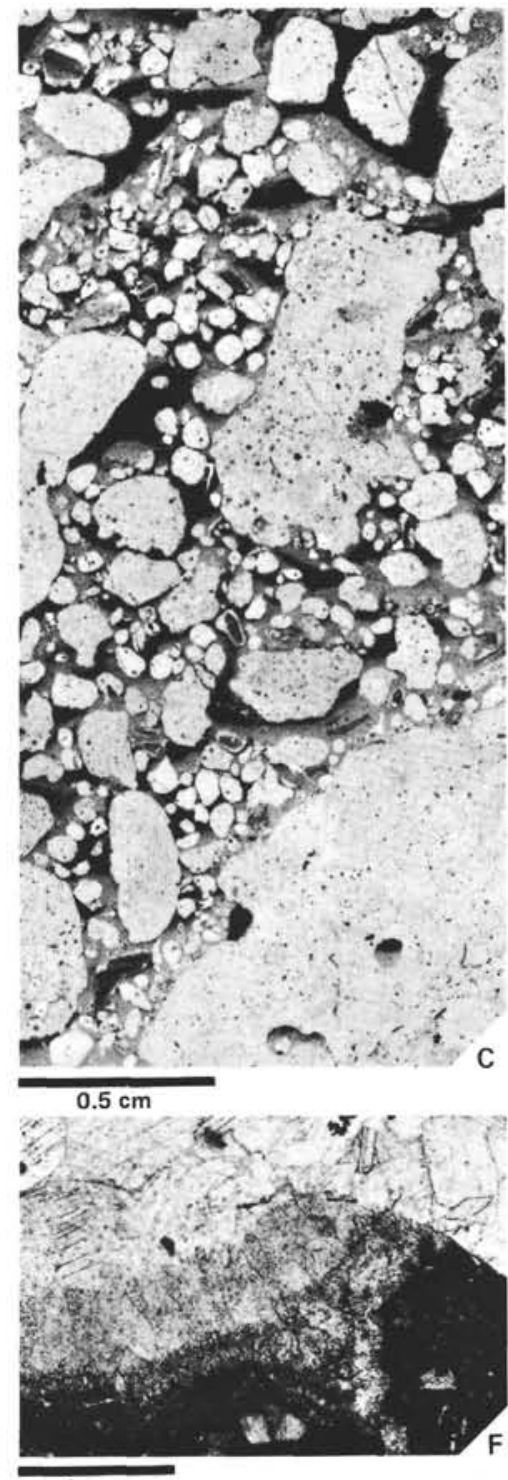

$1 \mathrm{~mm}$

Figure 7. Matrix-free to matrix-poor breccias, Lower to Middle Jurassic, Mediterranean Tethys and DSDP Site 547. A. Matrix-free breccia with lithoclasts of shallow-water limestones, rimmed by radiaxial fibrous calcite and with later red pelagic carbonate sediment in frame interstices. Note geopetal fabric in upper half of photograph. Rosso Ammonitico Toscano (lower part), Sinemurian, Monte Cetona, southeastern Tuscany, central Italy. Negative print from peel. B. Breccia with composite clasts, which in a matrix of biomicrite contain smaller clasts of various limestone types, mainly skeletal wackestones with bivalves, small ammonites, calcite-cemented radiolarian molds, foraminifers, some clasts also with shallow-water material including small cyanobacterial nodules. Geopetally infilled sediment drapes the walls of interstitial voids and is in turn overlain by blocky calcite cement. This internal sediment grades upward from light reddish micrite through layers with a clotty texture into darker reddish microspar. Subunit VIA, lower part, ?Pliensbachian, Sample 547B-11-1, 62-70 cm. Negative print from thin section. C. Breccia composed of irregularly shaped, more or less rounded clasts of different lithologies, mainly lime wackestones containing fine unidentified skeletal material, thin-shelled "pelagic" bivalves, calcite-cemented radiolarian molds, small ammonites, ostracodes, etc. The internal sediment consists of (1) granule-size smaller lithoclasts, cyanobacterial nodules, and biogenic components, and (2) a later geopetal infill of reddish carbonate sediment, now largely microsparite. Locally inclusion-rich spar, presumably replacing a former acicular cement lines cavities, preceding the final void-filling blocky calcite cement. Subunit VIA, lower part, ?Pliensbachian, Sample 547B-11-1, 127-129 cm. Negative print from thin section. D. Breccia with different generations of geopetal internal sediment. Interstices between irregularly shaped clasts of pelagic lime wackestone with small skeletal remains, bivalves, ammonites, calcite-cemented radiolarian molds, and ostracodes are filled by (1) darker reddish microsparite with pelagic biota (thin-shelled bivalves, radiolarians, Schizosphaerella), and (2) white coarse microspar. The two generations of interstitial sediment are separated by a thin fringe of calcite cement. Abundant schizosphaerellids in the younger infilled sediment show that microspar originated by neomorphism of pelagic lime mud. This breccia fills vertical dykes in pelagic deposits of late Pliensbachian age; the age of the infilled sediments is unknown. Furlo, Umbrian Apennines, central Italy. E. Matrix-free breccia with geopetal sediment of different grain size, overlain by blocky calcite cement. Different grain sizes in microspar probably reflect two different generations of infill. Subunit VIA, lower part, ?Pliensbachian, Sample 547B-11-3, 92-94 cm. Thin section, plane light. F. Detail of limestone breccia with clasts of shallow-water lithologies. Repeated brecciation is documented by broken rims of radiaxial fibrous calcite (replacing an earlier acicular cement, see Kendall and Tucker, 1973) that possibly lined interstitial cavities in an earlier breccia. (See A, earlier). The broken fabric is recemented by blocky sparite. Subunit VIA, lower part, Middle Jurassic to Oxfordian, Sample 547B-8-4, 43-46 cm. Thin section, plane light. 
lime wackestone with calcite-filled radiolarian molds, "pelagic" bivalves, and Globochaete. The nodules are set in a matrix of fossiliferous clay-rich microsparite with siltsized quartz and mica. Schizosphaerella occurs in the nodules and in the matrix. In turn, nodular limestone bands up to $4 \mathrm{~cm}$ thick enclose smaller nodules of lighter color. In 547B-10-4, 46-50 cm, an intercalation of a graded fine calcirudite to -arenite occurs that contains mainly round, cyanobacterial encrusted bioclasts (oncoids).

The breccias between 547B-10-2 and 547B-8-3 are poorly sorted and contain pebble- to granule- and sand-sized fragments of various limestone types (Fig. 4A, C): wackestone with radiolarians and ammonites, and packstone with a varied fauna of foraminifers, echinoderms, and mollusks. Many of the bioclasts and unbroken biota, including ammonites, are coated by cyanobacterian crusts. Frame interstices are often incompletely filled by sediment which is replaced by neomorphic microspar. Echinoderm fragments included in this groundmass bear commonly neomorphic syntaxial rims. The original voids above geopetal sediment are cemented by blocky calcite. Many of the pebbles are composite and bear evidence of repeated fracturing. Some of them include older generations of cement, also comprising radiaxial fibrous calcite fabrics (Fig 7F). The fabric of the breccias, along with the different generations of geopetal sediment and cement, is sometimes broken by later cracks which are, in turn, filled with red microsparite (Fig. 8B, C).

The breccias in the lower part of Subunit VIA bear evidence of a complex history of transport and deposition, probably involving submarine rock-fall and massflow processes. The constituent material most probably is derived from fault scarps active throughout the Liassic and possibly the early Middle Jurassic. Clastic deposits with corresponding structural, textural, and diagenetic characteristics are found associated with zones characterized by synsedimentary faulting in the Tethyan Jurassic (Fig. 7A, D). Refracturing of the breccias after deposition and partial cementation points to an environment in the immediate neighborhood of or on a faulted slope (Fig. 8). The regular bedding of the nodular limestones in Core 547B-10 (Fig. 9) suggests that mass movement played a minor part in their deposition except for the intercalation of the graded oncoidal calcarenite mentioned above.

We could not directly date the lower part of this subunit. Riegraf et al. (this volume) suggest a Pliensbachian age for Cores 547B-14 to 547B-11. A major stratigraphic break must therefore occur between Cores 547B-11 and 547B-10 which, according to the same authors, is of Middle Jurassic (Bajocian-Callovian) age.

\section{Subunit VIA, Upper Part (547B-6-1, $107 \mathrm{~cm}$ to}

\section{B-8-3, $145 \mathrm{~cm}$; 773 to $795.5 \mathrm{~m}$ sub-bottom)}

The upper part of Subunit VIA consists mainly of burrowed pelagic marls and marly limestones with a more or less pronounced nodular to flaser (Garrison and Kennedy, 1977) structure. Chondrites-type burrows are common. Intercalated redeposited breccias contain displaced shallow-water and pelagic material in variable proportions. In Core 547B-8, greenish gray or reddish brown, somewhat nodular to flaser-bedded marly limestones prevail. The nodules show a faintly pelleted texture and contain thin-shelled "pelagic" bivalves, echinoderm fragments, foraminifers, Globochaete, Protoglobigerina, rare aptychi, and small gastropods. The matrix is clay-rich microsparite with pelagic bivalves and echinodermal skeletal debris.

In Section 547B-8-3 several graded intercalations of redeposited skeletal limestones occur. They consist entirely of shells and shell fragments of "pelagic" bivalves, in most cases undetermined, but in part possibly referable to Bositra. Sheltered cavities beneath shells are cemented by blocky spar. The blocky calcite cement is typically preceded by a polycrystalline rim of bladed to fibrous calcite grown out syntaxially from the shells. Morphologically identical syntaxial rims similarly extend into the surrounding groundmass that is, in turn, partially replaced by neomorphic microspar (Fig. 10B, C).

In Core 547B-7 the pelagic sediment is again a burrowed, nodular to flaser-structured marly limestone; however, the fossil content is different and comprises larger aptychi, rhyncholiths, and frequent Saccocoma, apart from thin-shelled bivalves. Schizosphaerella is present in the nodules and in the clay-rich microsparite matrix, which also contains small scattered dolomite rhombs

Redeposited sediments are of different types. Red conglomeratic beds contain redeposited pelagic lithologies, possibly of somewhat greater age. These include marly wackestones with abundant "pelagic" bivalves and calcite-cemented radiolarian molds. Sediment gravity flow deposits with a major contribution from shallow-water sources comprise among other components lithic fragments of pelsparites, clotty limestones and oncoidal packstones, algae (Tubiphytes, Bacinella), coral and hydrozoan debris, foraminifers (e.g., Protopeneroplis), bryozoans, and various other biota, many of them encrusted by cyanobacterial material.

The breccias in 547B-6-1 to 547B-6-3 contain varying proportions of shallow-water material together with reworked wackestones rich in calpionellids. Interbedded nodular coccolith chalks are olive green, grayish green, and pale green in color.

The lithologies of parts of Core 547B-8 and of Core 547B-7 again compare well with pelagic sediments of similar age of the Tethyan Jurassic, i.e., the Rosso Ammonitico and Rosso ad Aptici facies. Low bulk sedimentation rates are probably related to periodic nondeposition and/or submarine erosion. Core 547B-8 possibly contains the nekto-planktonic bivalve Bositra and would then not be younger in age than Oxfordian (Jefferies and Minton, 1965), whereas Core 574B-7 is of Kimmeridgian age (Renz, this volume). Calpionellids place Core 547B-6 largely into the late Tithonian (Zones A [547B-6-3] and B [547B-6-2] of Allemann et al., 1971). Azéma and Jaffrezo (this volume) give an age of early Berriasian-late Tithonian to early Berriasian for this calpionellid-bearing interval (Zone B and lower part of Zone C of Allemann, et al., 1971). 


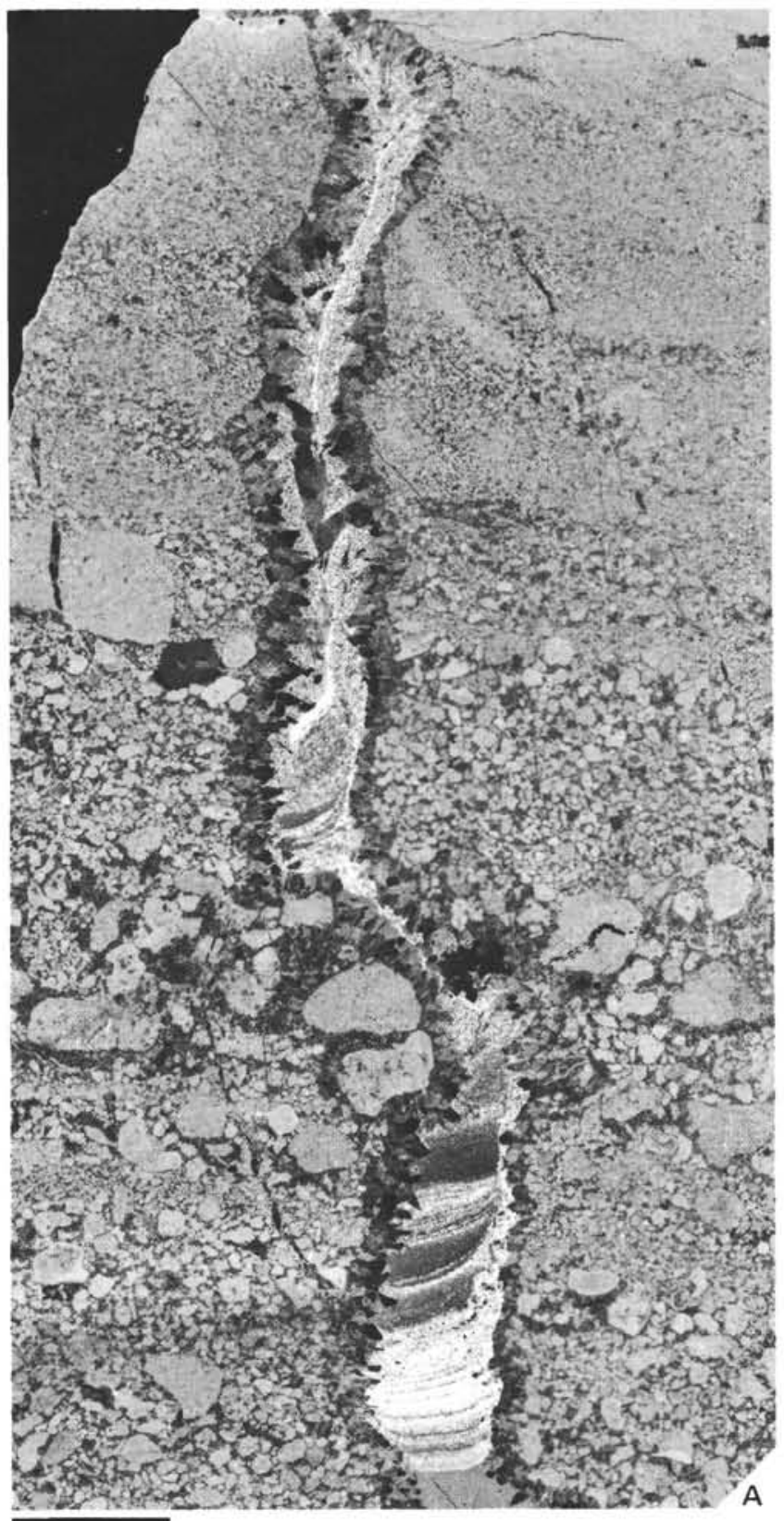

$5 \mathrm{~mm}$

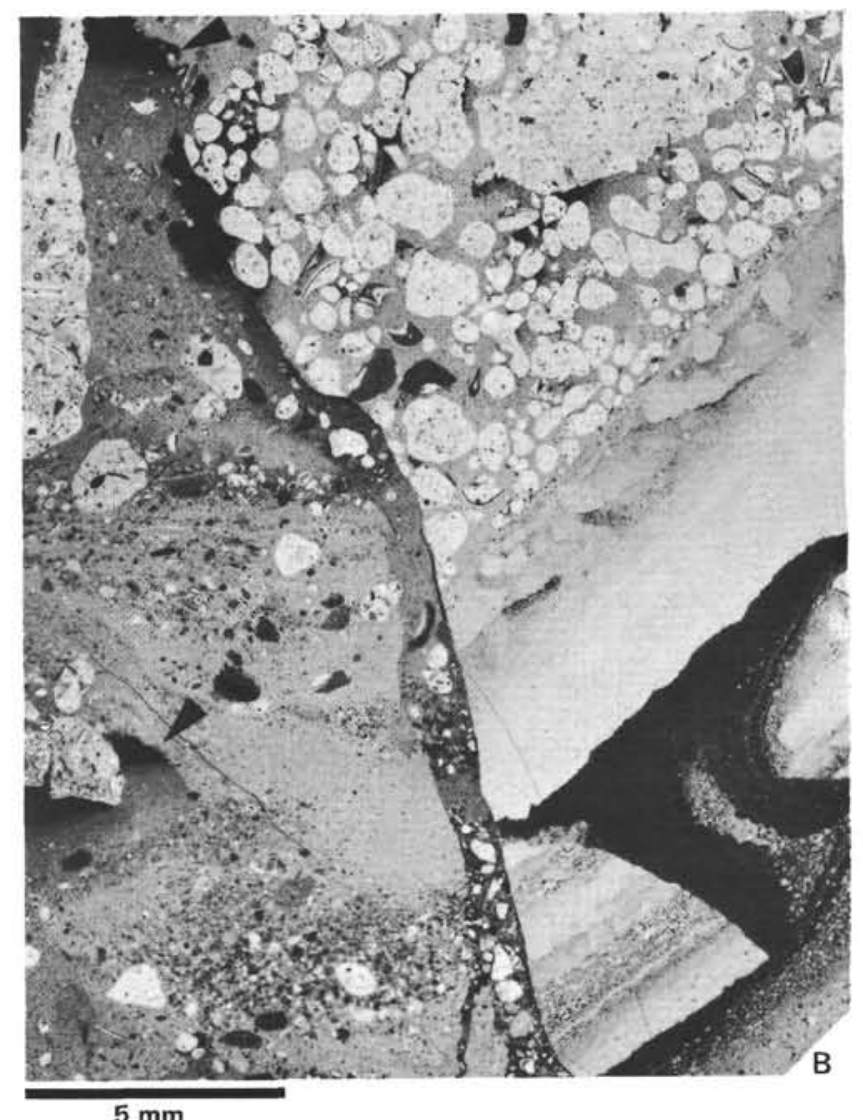

$5 \mathrm{~mm}$

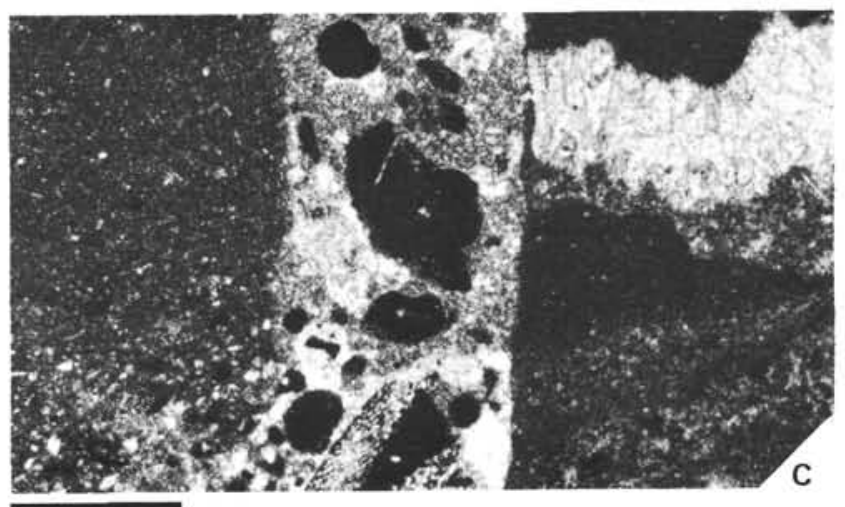

$0.5 \mathrm{~mm}$

Figure 8. Neptunian (sedimentary) dykes in sediment gravity flow breccias, Lower to Middle Jurassic, Mediterranean Tethys and DSDP Site 547. A. Graded fine calcirudite to calcarenite composed exclusively of displaced shallow-water material (mainly lithoclasts). Small "neptunian" sedimentary dyke is lined by radiaxial fibrous calcite and filled with younger laminated red pelagic carbonate sediment. White laminae are dolomitized. Rosso Ammonitico Toscano, lower part, Sinemurian, Monte Cetona, southeastern Tuscany, central Italy. Negative print from peel. B. Limestone breccia with fabric documenting complex genetic history. The clast in the upper right corner is similar to the lithology figured in Figure 7B, C; it shows early calcite cementation and geopetal interstitial sediment. At least two phases of later brecciation and sediment infill exhibiting local geopetal fabrics (arrows) can be distinguished. The youngest generation of interstitial sediment is a red microspar containing echinoderm fragments and some redeposited cyanobacterial nodules. Subunit VIB, lower part, Middle Jurassic, Sample 547B-9-1, $119-121 \mathrm{~cm}$. Negative print from thin section. C. Detail of B. Sedimentary dyke, cutting across earlier breccia components, geopetal internal sediment, and calcite cement. Dyke is filled by litho- and bioclasts embedded in reddish microspar. Thin section, plane light.

\section{GENERAL FACIES EVOLUTION AND COMPARISON WITH TETHYAN EQUIVALENTS}

The Sinemurian-Pliensbachian sediments at Site 547 record the first marine transgression in the central Atlantic with a rapid change from clastic continental sediments to hemipelagic and mass-flow deposits. This trans- gression obviously took place in area already differentiated into depressions and higher blocks by block faulting, as suggested by the facies evolution across the future margin (Winterer and Hinz, this volume). The rapid installation of a deeper-marine basin, without the intervening deposition of shallow-water platform carbonates, possibly reflects the flooding of intracontinen- 


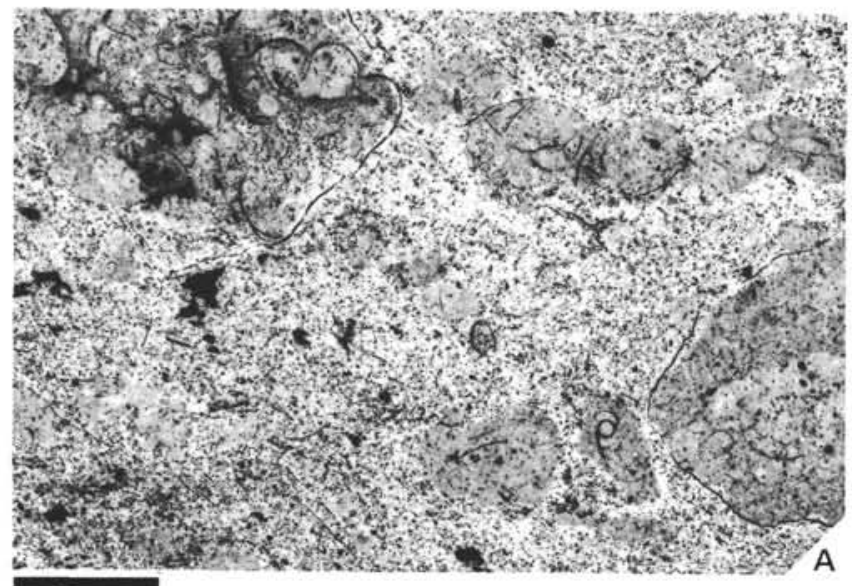

$3 \mathrm{~mm}$

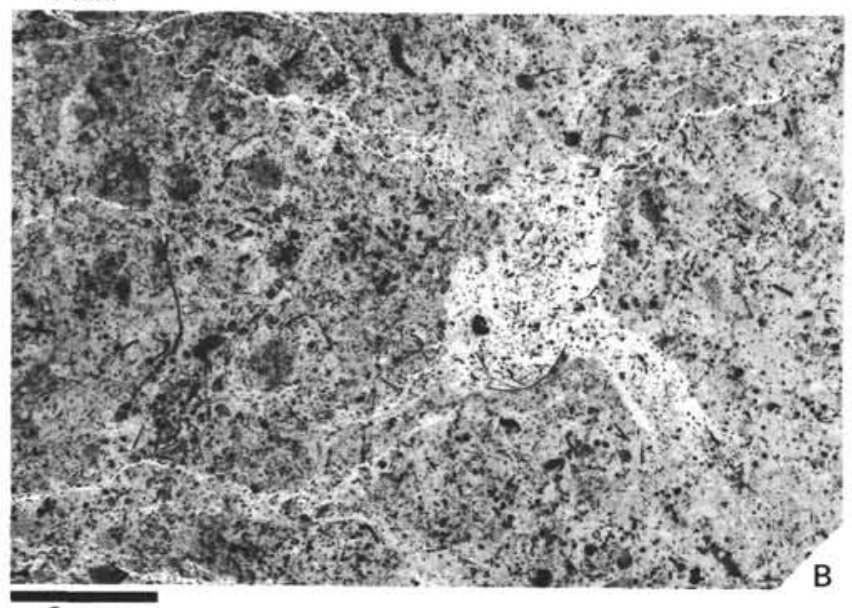

$3 \mathrm{~mm}$

Figure 9. Red nodular limestones, Rosso Ammonitico facies, Lower to Middle Jurassic, Site 547 and Mediterranean Tethys. A. Nodules of pelagic limestone with thin-shelled "pelagic" bivalves, small ammonites, and radiolarians set in a matrix of clay-rich microsparite rich in silt-sized detrital quartz and "pelagic" bivalves. Subunit VIA, lower part, Middle Jurassic, Sample 547B-10-3, 89-91 cm. B. Nodules of light-colored pelagic limestone with "pelagic" bivalves, small ammonites, calcite-cemented molds of radiolarians and sponge spicules, ostracodes, and foraminifers in a matrix of red clay-rich microsparite. Note incipient flaser-structure and microstylolitic contacts. Rosso Ammonitico Lombardo, ToarcianAalenian, Alpe Turati, Lombardian Zone, southern Alps, northern Italy. Negative prints from thin sections.

tal rift basins situated below global sea level; the Triassic evaporite deposits would then necessarily be of continental origin or derive from Tethyan waters spilled over or infiltrated episodically, through topographic barriers, from the western Mediterranean area.

Ongoing synsedimentary faulting during the Sinemurian-Pliensbachian and the presence of steep submarine topographic gradients is suggested at Site 547 by frequent sediment gravity flow deposits with a variety of clasts of both shallow- and deeper-water origin. The sediments of Subunit VIB and of the lower part of Subunit VIA compare well with basinal synrift sediments deposited along the embryonic continental margins of the Tethyan belt (Fig. 11). However, in the central and eastern Mediterranean area where Early Jurassic rifting oc- curred in a marine realm, the basinal synrift sediments overlie drowned carbonate platforms (see Fig. 11; for detailed facies descriptions and reconstructions of the paleotectonic evolution, see, e.g., Bernoulli, 1972; 1981; Bernoulli and Jenkyns, 1974; Winterer and Bosellini, 1981). In the down-faulted troughs off the still persisting carbonate platforms, these synrift sediments typically are limestones, some rich in spicules of siliceous sponges (Wiedenmayer, 1980), often with bands or nodules of replacement chert and with thin marl interbeds. There is a continuous spectrum of lithologies ranging from dark-colored, siliceous, spongolithic limestones (Fleckenkalk, Lombardian Siliceous Limestone) to light-colored calcilutites with a lesser clay content and calcite-cemented radiolarian molds (Corniola, Siniais Limestone).

In the Mediterranean area, the thickness of these deposits locally amounts to $1000 \mathrm{~m}$ and more. The expanded nature of the sediments and their depositional geometry, along with the associated sediment gravity flow deposits again similar to some of those observed at Site 547 (Fig. 4), suggest that these formations have been deposited in morphological basins bounded by active faults (Bally et al., 1981).

From the high average sedimentation rates (locally exceeding $100 \mathrm{~mm} / 10^{3} \mathrm{y}$.) of these basinal deposits, we must infer that most of the sediment was supplied from other than pelagic sources. Although the remains of calcareous nannoplankton (mainly Schizosphaerella) are ubiquitous, their volumetric importance is probably negligible (Kälin, 1980). Bank- and platform-derived carbonate lutum of multimineralogical composition, redeposited by surface currents and in intermediate waters, most probably contributed to the fine-grained carbonate of more calcareous facies types (peri-platform ooze, Schlager and James, 1978). Such a composition is similarly suggested for the fine carbonate sediment at Site 547. In the darker colored, more argillaceous facies types (Lombardian Siliceous Limestone), clay minerals derived from emergent areas and spicules derived from siliceous sponges, possibly populating basin slope environments, become important. Both were redistributed over the basin floor by slowly moving, dilute turbidity flows and/ or bottom currents (Kälin and Trümpy, 1977; Wiedenmayer, 1980).

The Liassic sediments at Site 547 are similar in facies, but thinner than their equivalents in Tethyan synrift basins; there is also a distinct interval of nodular pelagic limestones in the Lower to Middle Liassic (upper part of Subunit VIB). In general, however, the very proximal nature of the interbedded, matrix-poor to -free breccias higher in the section (Fig. 7) together with the low overall sedimentation rate points to very unstable conditions in the neighborhood of or on a faulted submarine slope. This inference is supported by the occurrence of complex breccia fabrics with successive generations of sedimentary dykes cutting through the earlier clast fabrics (Fig. 8; see also Wiedenmayer, 1963).

After a hiatus, possibly comprising the Upper Liassic and lowermost Middle Jurassic interval, sedimentation rates remained generally low as the margin sunk to greater 


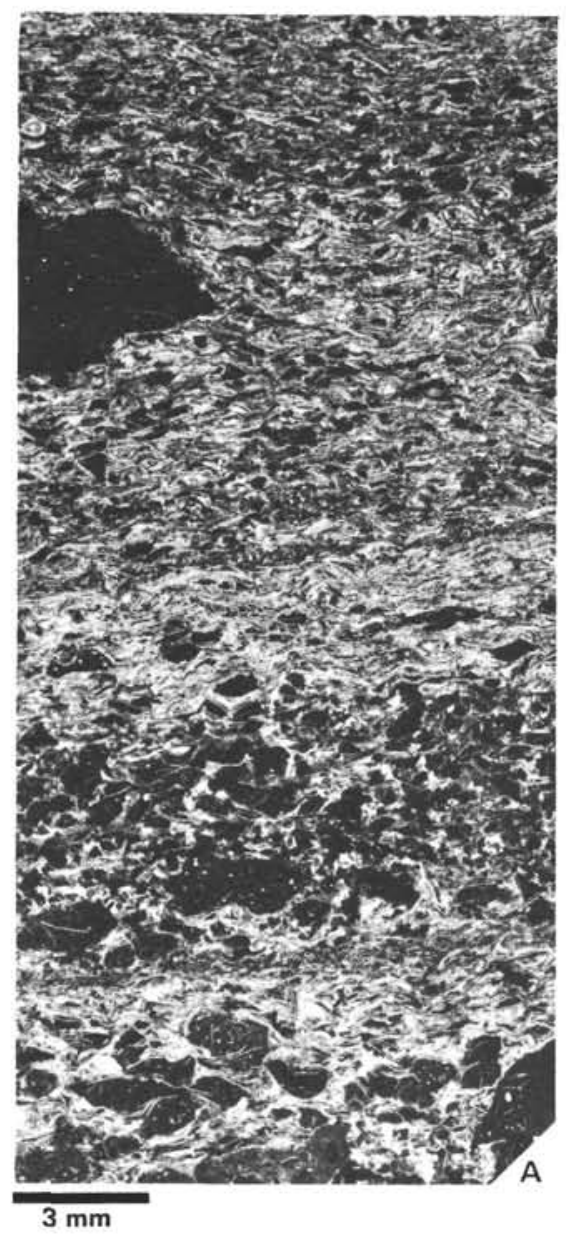

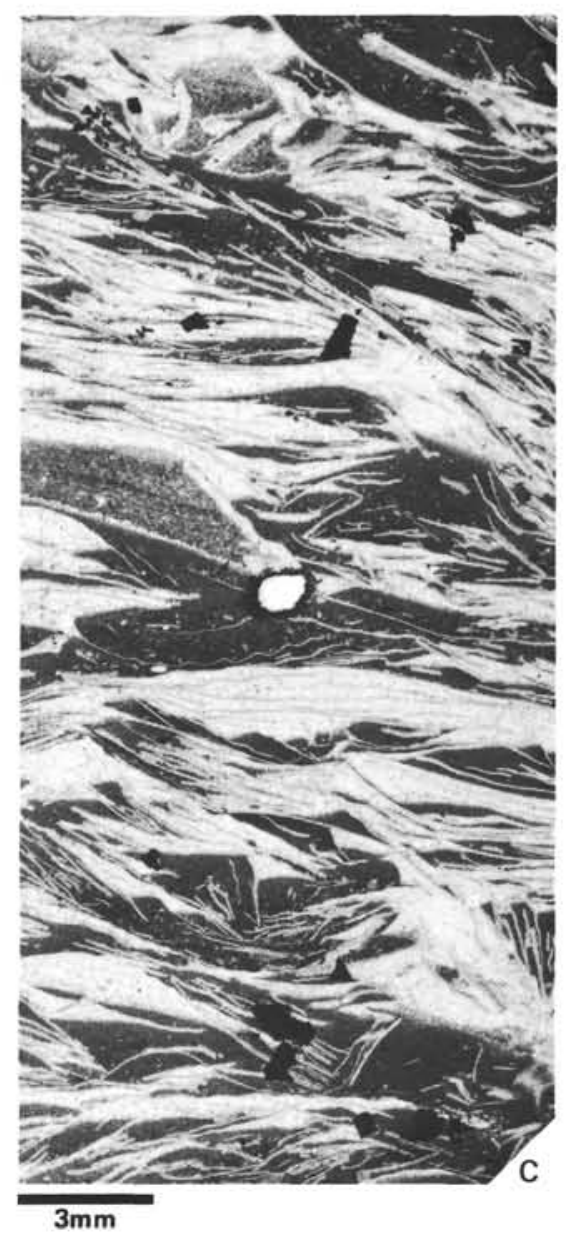

$3 \mathrm{~mm}$

Figure 10. Redeposited pelagic sediments. Middle to Upper Jurassic, Mediterranean Tethys and Site 547. A. Graded and laminated fine calcirudite to calcarenite with granules and smaller fragments of skeletal lime wackestone and thin-shelled "pelagic" bivalves and their fragments. Middle Jurassic, Kouklessi, Louros Valley, Ionian Zone, Greece (Bernoulli and Renz, 1970, section A). B. Calcirudite with sparse granules of pelagic lime wackestones, set in a matrix of microsparite with thin-shelled "pelagic" bivalves, overlain by bivalve packstone. Sheltered cavities beneath shells exhibit geopetal arrangement of sediment, now largely microsparite, overlain by blocky calcite cement. Syntaxial overgrowth on the pelagic bivalves is partly true cement (roofs of sheltered cavities), partly of neomorphic origin and replaces the embedding sediment. Subunit VIA, Middle Jurassic to Oxfordian, Sample 547B-8-3, 54-57 cm. C. Detail of graded skeletal limestone with "pelagic" bivalves, in part possibly Bositra. Subunit VIA, Middle Jurassic to Oxfordian, Sample 547B-8-3, 62-65 cm. Thin sections, plane light.

depth. Again, the facies encountered in the Middle to Upper Jurassic of Site 547 are very similar to those found on Jurassic Tethyan margins and the sequence of microfacies is also comparable (e.g., Bernoulli, 1972; Bernoulli and Jenkyns, 1974; Bernoulli et al., 1979; Kälin et al., 1979; Winterer and Bosellini, 1981). Nodular limestones of Rosso Ammonitico-type in Core 547B-10 (Fig. 9) contain abundant fragments of thin-shelled "pelagic" bivalves; upsection, a number of turbiditic layers in Core 547B-8 contain unbroken shells of "pelagic" bivalves possibly referable to the genus Bositra (Fig. 10). Finally, the limestones of Core 547B-7 show the typical facies of the Kimmeridgian-lower Tithonian Rosso ad Aptici with frequent aptychi, rhyncholiths, and Saccocoma. There is also an increase in redeposited pelagic sediment upsection with respect to shallow-water material that, in turn, reflects more open marine conditions than that occurring in the Liassic redeposited sediments. The redeposited beds, however, together with the low overall sedimentation rate still point to unstable conditions along a submarine faulted slope, with part of the resedimented material probably derived from the offshore high documented at Site 544. Evidence for sinking to a depth below the calcite compensation surface, as occurred along the distal Tethyan margins by the Middle to Late Jurassic (Bernoulli et al., 1979; Kälin et al., 1979) is, however, not found in the Mazagan transect.

\section{ACKNOWLEDGMENTS}

We are grateful to the Deep Sea Drilling Project and particularly to E. L. Winterer for the opportunity to study core samples from Site 547 . Financial support for this study came from the Swiss National Science Foundation (Grant 2.650-0.80). R. Guggenheim provided facilities at the SEM Laboratory at the Geologisches Institut der Universität, Basel; S. Bowald and T. Catin operated the SEM and prepared the photomicrographs. We thank P. O. Baumgartner, B. C. Schreiber, A. Spinnler, and L. Strasser for their help. H. C. Jenkyns, R. M. Leckie, A. Matter, K. Perch-Nielsen, and H. Weissert reviewed the manuscript. 


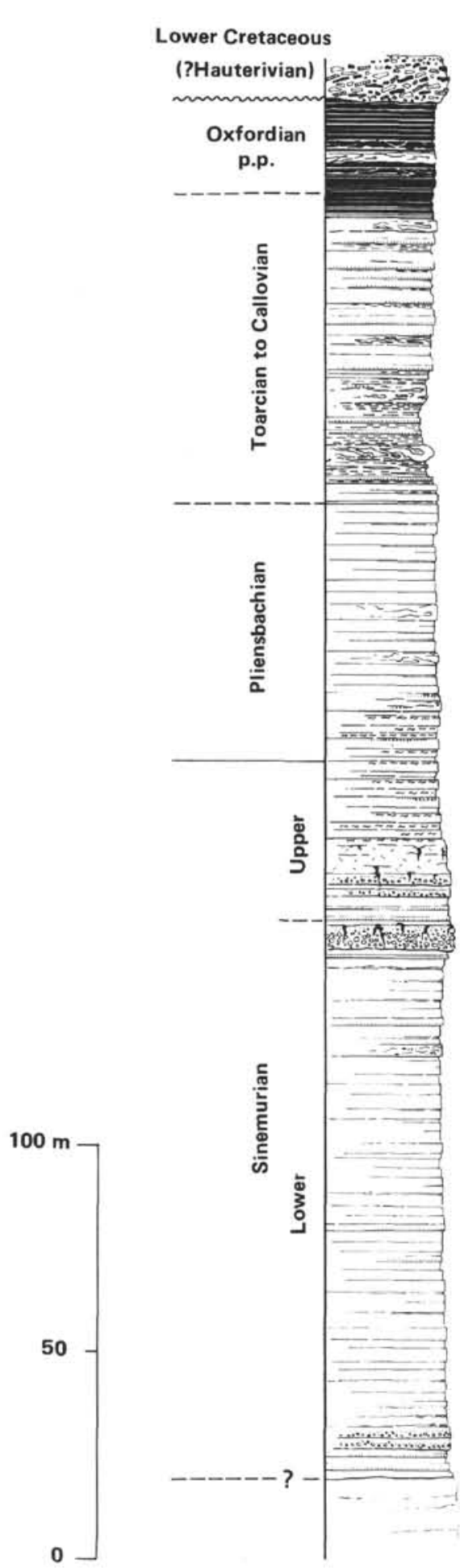

\begin{tabular}{l}
$\begin{array}{l}\text { Polygenic breccia with planar/imbricated clast fabric } \\
\text { (debris flow-deposit), redeposited pelagic material and } \\
\text { older lithologies (shallow- and deeper-water facies). } \\
\text { Maiolica Deep-marine erosional gap }\end{array}$ \\
Thin-bedded, p.p. current-laminated red and green \\
radiolarian cherts with shale partings; rare slump sheets. \\
Marne a Posidonia \\
Upper part: \\
prevailing mass-flow deposits: \pm m-thick turbiditic \\
marlstones with a basal layer of skeletal grainstone \\
(pelagic bivalves, radiolarians, crinoid ossicles, some \\
intraformational lithoclasts). \\
Lower part: \\
prevailing red hemipelagic marls, p.p. nodular, with \\
ammonites; skeletal grainstones (lag deposits); turbidites \\
with pelagic bivalves, and intraformational slumping \\
near base; small-pebble/granule conglomerates with \\
mixed hemipelagic and displaced shallow-water material. \\
\hline Calcare Selcifero (upper part) \\
Thin- to medium-bedded light grey calcilutites and \\
current-laminated calcisiltites with replacement chert, \\
rich in Schizosphaerel/a punctulata. \\
Intraformational slump sheets. \\
\hline
\end{tabular}

Rosso Ammonitico Toscano

Upper part:

red nodular to flaser-structured biomicrites; occasional thin and discontinuous intraformational conglomerates.

Lower part:

background sedimentation: irregularly, generally thickbedded reddish cephalopod/crinoid limestone, rich in Schizosphaerella astrea.

Mass-flow deposits: thick (up to $7 \mathrm{~m}$ ) matrix-free/

$\checkmark$-poor breccias with only shallow-water lithoclasts, rimmed by radiaxial fibrous calcite and with later red pelagic internal carbonate sediment in frame interstices and dykes (Fig. 7A, 8A); redeposited thin

calcarenites with isolated shallow-water particles.

Calcare Selcifero (lower part)

Background sedimentation: medium- to thin-bedded grey burrowed spongolithic limestones with replacement chert (periplatform ooze):

mass-flow deposits: turbidites and debris flow-deposits with penecontemporaneously displaced shallow-water

\pm deeper-marine material, local dolomitization; occasional slump sheets.

Condensed

\section{Calcare Massiccio}

Carbonate

Dolomitized shallow-water carbonates.
Figure 11. The Jurassic sequence of Monte Cetona (southeastern Tuscany, central Italy), a continental margin section of the southern Tethys. Typical features of this sequence include the drowning of a carbonate platform (Calcare Massiccio) in the course of early Liassic rifting; deposition of basinal (Calcare Selcifero) and episodically condensed (Rosso Ammonitico Toscano, in particular, lower part) synrift sediments of early to middle Liassic age, followed by a deepening-upward sequence of pelagic and turbiditic postrift sediments characterized by facies reflecting increasing carbonate solution (Marne a Posidonia, Diaspri). Decrease of redeposited shallow-water material and increase in pelagic components in carbonate turbidites upsection reflect the step-wise reduction of former shallow-water sites. Synsedimentary tensional tectonics are documented by "neptunian dykes" in thick-bedded, condensed, cephalopod-crinoid limestones and matrixpoor or -free breccias (Rosso Ammonitico Toscano, lower part, see Fig. 8A) (Kälin and Patacca, in preparation). 


\section{REFERENCES}

Allemann, F., Catalano, R., Farès, F., and Remane, J., 1971. Standard calpionellid zonation (Upper Tithonian-Valanginian) of the western Mediterranean Province. In Farinacci, A. (Ed.), Proc II Planktonic Conf.: Rome (Edizioni Tecnoscienza), 2:1337-1340.

Bally, A. W., Bernoulli, D., Davis, G. A., and Montadert, L., 1981. Listric normal faults. In Geology of Continental Margins, Proc. Int. Geol. Congr., Oceanol. Acta, 1981, No. SP, pp. 87-102.

Bernoulli, D., 1972. North Atlantic and Mediterranean Mesozoic facies: a comparison. In Hollister, C. D., Ewing, J. I., et al., Init. Repts. DSDP, 11: Washington (U.S. Govt. Printing Office), 801-871.

1981. Ancient continental margins of the Tethyan ocean. In Bally, A. W., et al. (Eds.), Geology of Passive Continental Margins, Am. Assoc. Pet. Geol., Educ. Course Note Ser., 19: 5-1-5-36.

Bernoulli, D., and Jenkyns, H. C., 1970. A Jurassic Basin: The Glasenbach Gorge, Salzburg, Austria. Verh. Geol. Bundes-Anst., Vienna: 504-531.

1974. Alpine, Mediterranean and central Atlantic Mesozoic facies in relation to the early evolution of the Tethys. In Dott, R. H., and Shaver, R. H. (Eds.), Modern and Ancient Geosynclinal Sedimentation. Soc. Econ. Paleontol. Mineral. Spec. Publ., 19: 129-160.

Bernoulli, D., Kälin, O., and Patacca, E., 1979. A sunken continental margin of the Mesozoic Tethys: the Northern and Central Apennines. Publ. Spec. Assoc. Sedimentol. Franc., 1:197-210.

Bernoulli, D., and Renz, O., 1970. Jurassic carbonate facies and new ammonite faunas from Western Greece. Eclogae Geol. Helv., 63: 573-607.

Bhat, H., McMillan, N. J., Aubert, J., Porthault, B., and Surin, M., 1975. North American and African drift-the record in Mesozoic coastal plain rocks, Nova Scotia and Morocco. In Yorath, C. J., et al. (Eds.), Canadian Continental Margins and Offshore Petroleum Potential. Mem. Can. Soc. Pet. Geol., 4:375-389.

de Graciansky, P.-Ch., Bourbon, M., Charpal, O., Chenet, P. -Y., and Lemoine, M., 1979. Genèse et évolution comparées de deux marges continentales passives: marge ibérique de l'Océan Atlantique et marge européenne de la Téthys dans les Alpes occidentales. Bull. Soc. Geol. France, 21:663-674.

Garrison, R. E., and Kennedy, W. J., 1977. Origin of solution seams and flaser structure in Upper Cretaceous chalks of southern England. Sediment. Geol., 19:107-137.

Jansa, L. F., 1981. Mesozoic carbonate platforms and banks of the eastern North American margin. Mar. Geol., 44:97-117.

Jansa, L. F., and Wiedmann, J., 1982. Mesozoic-Cenozoic development of the eastern North American and Northwest African continental margins: a comparison. In von Rad, U., Hinz, K., et al. (Eds.), Geology of the Northwest African Continental Margin: Berlin (Springer Verlag), 215-269.

Jefferies, R. P. S., and Minton, P., 1965. The mode of life of two Jurassic species of "Posidonia" (Bivalva). Palaeontology, 8:156-185.
Kälin, O., 1980. Schizosphaerella punctulata Deflandre \& Dangeard: Wall ultrastructure and preservation in deeper-water carbonate sediments of the Tethyan Jurassic. Eclogae Geol. Helv., 73:983-1008.

Kälin, O., Patacca, E., and Renz, O., 1979. Jurassic pelagic deposits from Southeastern Tuscany; aspects of sedimentation and new biostratigraphic data. Eclogae Geol. Helv., 72:715-762.

Kälin, O., and Trümpy, D. M., 1977. Sedimentation und Paläotektonik in den westlichen Südalpen: Zur triasisch-jurassischen Geschichte des Monte Nudo-Beckens. Eclogae Geol. Helv., 70: 295-350.

Kendall, A. C., and Tucker, M. E., 1973. Radiaxial fibrous calcite: a replacement after acicular carbonate. Sedimentology, 20:365-389.

Lancelot, Y., 1980. Birth and evolution of the "Atlantic Tethys" (Central North Atlantic). Colloq. 26th Int. Geol. Congr., Paris, C5: 215-223.

Lancelot, Y., and Winterer, E. L., 1980. Evolution of the Moroccan Oceanic Basin and adjacent Continental margin-a synthesis. In Lancelot, Y., Winterer, E. L., et al., Init. Repts. DSDP, 50: Washington (U.S. Govt. Printing Office), 801-821.

Manspeizer, W., Puffer, J. H., and Cousminer, H. L., 1978. Separation of Morocco and eastern North America: A Triassic-Liassic stratigraphic record. Geol. Soc. Am. Bull. 89:901-920.

Renz, O., Imlay, R., Lancelot, Y., and Ryan, W. B. F., 1975. Ammonite-rich Oxfordian limestones from the base of the continental slope off Northwest Africa. Eclogae Geol. Helv., 68:432-448.

Ryan, W. B. F., and Miller, E. L., 1981. Evidence of a carbonate platform beneath Georges Bank. Mar. Geol., 44:213-228.

Schlager, W., 1980. Mesozoic calciturbidites in Deep Sea Drilling Project Hole 416A-Recognition of a drowned carbonate platform. In Lancelot, Y., Winterer, E. L., et al., Init. Repts. DSDP, 50: Washington (U.S. Govt. Printing Office), 733-749.

Schlager, W., and James, N. P., 1978. Low-magnesian calcite limestones forming at the deep-sea floor, Tongue of the Ocean, Bahamas. Sedimentology, 25:675-702.

Van Houten, F. B., 1977. Triassic-Liassic deposits of Morocco and eastern North America: comparison. Am. Assoc. Pet. Geol. Bull., 61:79-99.

Wiedenmayer, F., 1963. Obere Trias bis mittlerer Lias zwischen Saltrio und Tremona (Lombardische Alpen). Eclogae Geol. Helv., 56: 529-640.

1980. Spiculites and sponges in the Lower Jurassic of the Western Tethys. In Hartman, W. D., Wendt, J. W., and Wiedenmayer, F. (Eds), Living and Fossil Sponges: Sedimenta VIII, pp. 135-168.

Winterer, E. L., and Bosellini, A., 1981. Subsidence and sedimentation on Jurassic passive continental margin, Southern Alps, Italy. Am. Assoc. Pet. Geol. Bull., 65:394-421.

Date of Initial Receipt: March 24, 1983

Date of Acceptance: August 25, 1983 